\title{
The Interpretation of Exhaled Nitric Oxide Values in Children With Asthma Depends on the Degree of Bronchoconstriction and the Levels of Asthma Severity
}

\author{
Tomasz Grzelewski MD PhD, Paweł Majak MD PhD, Joanna Jerzyńska MD PhD, \\ Włodzimierz Stelmach MD PhD, Rafał Stelmach MD, Anna Janas MD PhD, \\ Aleksandra Grzelewska MSc, Konrad Witkowski MD, \\ Eusebio Makandjou-Ola MD PhD, and Iwona Stelmach MD PhD
}

\begin{abstract}
BACKGROUND: The clinical implications of fractional exhaled nitric oxide $\left(F_{E N O}\right)$ measurements in childhood asthma are unclear. We aimed to evaluate the relationship between the level of exhaled nitric oxide and pre-bronchodilator $\mathrm{FEV}_{1}$ and the change in $F E V_{1}$ after bronchodilator in children with asthma. METHODS: This was a retrospective, cross-sectional study. We evaluated data from medical documentation of children with asthma with special attention to $F_{E N O}$ results, asthma severity, FEV $_{1}$ (\% predicted), and bronchial reversibility test. RESULTS: Four hundred and five subjects (age 6-18 y) completed the study. Median levels of $F_{E N O}$ increased linearly with subjects' age $(P=.03)$. We found a nonlinear trend of pre-bronchodilator $F_{E V}$ across 4 quartiles of $F_{E N O}$ in episodic and mild asthma; we observed lower pre-bronchodilator $\mathrm{FEV}_{1}$ in children with higher $F_{E N O}$, but only up to the $F_{E N O}$ value of $35.4 \mathrm{ppb}$; in children with $F_{E N O}$ value $>35.4 \mathrm{ppb}$, prebronchodilator $\mathrm{FEV}_{1}$ was increased. We found a linear increasing trend of change from baseline (after $400 \mu \mathrm{g}$ of salbutamol) in $\mathrm{FEV}_{1}$ across $\mathrm{F}_{\mathrm{ENO}}$ categories in children with moderate asthma. CONCLUSIONS: Our results suggest a need to measure $\mathbf{F}_{\mathrm{ENO}}$ before as well as after spirometry. Consequently, in children with asthma with bronchial obstruction, we suggest assessing $\mathbf{F}_{\mathrm{ENO}}$ after short-acting $\boldsymbol{\beta}_{\mathbf{2}}$ agonists as well. (ClinicalTrials.gov registration NCT00815984.) Key words: $F_{E N O}$; $F E V_{1}$; asthma; children; airway caliber; glucocorticosteroids; asthma severity. [Respir Care 2014;59(9):1404-1411. (C) 2014 Daedalus Enterprises]
\end{abstract}

\section{Introduction}

The current concept of asthma pathogenesis underlines a chronic inflammatory process, which causes air flow

Drs Grzelewski, Majak, Jerzyńska, and I Stelmach are affiliated with the Department of Pediatrics and Allergy, Medical University of Lodz, N Copernicus Hospital; Dr W Stelmach is affiliated with the Department of Social and Preventive Medicine, Medical University of Lodz; Drs R Stelmach and Janas are affiliated with the Institute of Dental Surgery, Faculty of Medicine and Dentistry, Medical University of Lodz; Ms Grzelewska is affiliated with the Faculty of Nursing and Midwifery, Division of Nursing, Medical University of Lodz; Dr Witkowski is affiliated with Military Teaching Hospital No. 2, Medical University of Lodz; and Dr Makandjou-Ola is affiliated with the Department of Laboratory Diagnostics, Medical University of Lodz, N. Barlicki Hospital, Lodz, Poland.

None of the authors have disclosed a conflict of interest. obstruction and bronchial hyper-responsiveness. ${ }^{1}$ The exact pathophysiological role of nitric oxide (NO) in the airways and lungs is complex..-4 On the one hand, it may act as a pro-inflammatory mediator predisposing to the development of airway hyper-responsiveness; on the other hand, under physiological conditions, it acts as a weak mediator of smooth muscle relaxation and protects against airway hyper-responsiveness. ${ }^{2-7}$ Recently, it has been proved that $\mathrm{F}_{\mathrm{ENO}}$ results are in disagreement with other measurements of asthma control in children with asthma,

Correspondence: Iwona Stelmach MD PhD, Department of Pediatrics and Allergy, N Copernicus Hospital, 62 Pabianicka Street, 93-513 Lodz, Poland E-mail: alergol@kopernik.lodz.pl.

DOI: $10.4187 /$ respcare.02889 
namely spirometry, children's asthma control test, and conventional clinical assessment. ${ }^{8}$ Green et $\mathrm{al}^{8}$ showed that mean $\mathrm{F}_{\mathrm{ENO}}$ in pediatrician-judged uncontrolled asthma was double that of controlled asthma. $\mathrm{F}_{\mathrm{ENO}}$ correlates with bronchial reactivity ${ }^{9}$ and decreases with anti-inflammatory asthma therapy, such as inhaled corticosteroids (ICS) and anti-leukotrienes, in children. ${ }^{10} \mathrm{~F}_{\mathrm{ENO}}$ values can be affected by several factors. ${ }^{2}$ We are aware of the fact that most children with asthma have normal $\mathrm{FEV}_{1}$ outside acute attacks; however, to date, no study has assessed the influence of the degree of baseline bronchoconstriction on $\mathrm{F}_{\mathrm{ENO}}$ results in children. ${ }^{11,12}$ Current guidelines suggest the use of cut points rather than reference values when interpreting $\mathrm{F}_{\mathrm{ENO}}$ results, but this recommendation is weak, based on evidence of low quality. ${ }^{2}$ Therefore, our analysis was focused on investigating the relationship between $\mathrm{F}_{\mathrm{ENO}}$ measurements and the degree of bronchoconstriction. Specifically, we evaluated the relationship between the level of exhaled nitric oxide and pre-bronchodilator $\mathrm{FEV}_{1}$ and the change in $\mathrm{FEV}_{1}$ after bronchodilator in children with asthma.

\section{Methods}

\section{Study Design}

The study was retrospective and cross-sectional, and was performed at the Department of Pediatrics and Allergy, Medical University of Lodz, N Copernicus Hospital (Lodz, Poland). We evaluated data from medical documentation of 943 children (age 6-18 y) with symptoms suggestive of asthma, who attended our out-patient allergy clinic from January 2008 to March 2009. We included subjects with at least $2 \mathrm{y}$ of clinical observation, whose asthma was either confirmed or excluded. Children with asthma and allergic rhinitis (64\%) were also included. The 405 subjects analyzed had $\mathrm{F}_{\mathrm{ENO}}$ measurement, spirometry, and bronchial reversibility test performed at the same visit. The diagnosis and the severity of asthma and allergic rhinitis were universally established by the medical doctors (all doctors involved were from our out-patient allergy clinic) according to standard definitions of both diseases in the latest guidelines. ${ }^{1,13}$ Diagnosis of asthma was universally established by allergy specialists on the basis of the symptoms of asthma, the findings of the physical examination of the respiratory system, and the improvement in the pre-bronchodilator $\mathrm{FEV}_{1} \geq 12 \%$ after the administration of salbutamol $(200 \mu \mathrm{g})$ in all patients. ${ }^{1}$ Medical documentation of the subjects was analyzed with special attention to the results of $\mathrm{F}_{\mathrm{ENO}}$, spirometry, bronchial reversibility test, and allergic rhinitis diagnosis, as well as allergen sensitization and treatment. Non-atopic children with asthma who showed normal $\mathrm{F}_{\mathrm{ENO}}$ values were excluded from the analysis. We analyzed the mean doses of

\section{QUICK LOOK}

\section{Current knowledge}

Exhaled nitric oxide concentrations have been shown to increase in a variety of disorders associated with lung inflammation. The usefulness of measuring exhaled nitric oxide in monitoring disease progression or disease management has not been proven.

\section{What this paper contributes to our knowledge}

Exhaled nitric oxide concentrations increased linearly with age, but the relationship of exhaled nitric oxide and $\mathrm{FEV}_{1}$ demonstrated only a nonlinear trend. Exhaled nitric oxide should be measured before and after the $\mathrm{FEV}_{1}$ measurement. Exhaled nitric oxide alone was not a discriminator of lung inflammation or degree of dysfunction.

inhaled glucocorticosteroids, which were assessed throughout the period of 3 months preceding the measurements of $\mathrm{F}_{\mathrm{ENO}}$ and spirometry (the dose of inhaled glucocorticosteroid was stable throughout that period in children with asthma). Children had been on inhaled glucocorticosteroids since the diagnosis of asthma. Inhalation technique was routinely checked at each visit by allergy specialists in our out-patient allergy clinic. All patients with asthma in this study were controlled. For the purpose of this study, we categorized our patients according to the level of treatment into the following study groups: an episodic/low steroid daily use (episodic asthma), a medium steroid daily use (mild asthma), or a high steroid daily use (moderate asthma). Such an approach allowed us to obtain almost equal sample size in the study groups; therefore, it facilitated statistical analysis. The healthy group consisted of patients in whom asthma and allergic rhinitis were excluded and who were free of any kind of current illnesses. All tests among the healthy subjects were performed during differential diagnosis of asthma. Subjects from the healthy group were children with no asthma and with no atopy according to a negative prick test for common inhalant and food allergens; none had respiratory tract symptoms nor were treated with any drug in the 2 months preceding the evaluation of the results. The study was approved by the medical ethical committee of the Medical University of Lodz, Lodz, Poland. All parents or guardians of the patients gave their oral and written consent for the evaluation of data from medical documentation of their children. The study was registered at www.ClinicalTrials.gov as NCT00815984. 


\section{BRONCHOCONSTRICTION AND EXHALED NitRIC OXIDE}

\section{Allergen Sensitization}

All subjects underwent skin prick test with common inhalant and food allergens (allergy profile): Dermatophagoides farinae, Dermatophagoides pteronyssinus, Alternaria, Cladosporium, cat dander, dog dander, mixed grass pollen, rye, birch, hazel, ribwort, alder, motherwort, feather, cocoa, milk, egg, and peanut. Positive (histamine chloride, $10 \mathrm{mg} / \mathrm{mL}$ ) and negative (glycerol) controls (extracts from Nexter-Allergopharma, Reinbek, Germany) were also used. A positive skin prick test reaction was defined as a mean wheal diameter $>3 \mathrm{~mm}$ in excess of the negative control. Atopy was defined as a positive skin test response to any of the 18 allergens tested.

\section{Nitric Oxide Measurement}

In our out-patient allergy clinic, $\mathrm{F}_{\mathrm{ENO}}$ was measured before a forced flow-volume curve measurement and bronchial reversibility test in all subjects on the same day (in the morning, between $9 \mathrm{Am}$ and $11 \mathrm{AM}$ ). The NO measurements were performed according to the European Respiratory Society/American Thoracic Society recommendations, ${ }^{14}$ with a chemiluminescence analyzer (model 280i nitric oxide analyzer, Sievers, Boulder, Colorado) and defined in parts per billion. The analyzer provides an online continuous measurement of $\mathrm{NO}$ in a single exhalation with a detection range of 0.1-500 ppb. Environmental NO was measured before and after each test, and it never exceeded 5 ppb. Dead space and nasal NO (which are reflected by the NO concentration peak during exhalation) and NO from the lower respiratory tract (determined by the plateau value after the peak) were recorded automatically by using the manufacturer's software. Three $\mathrm{F}_{\mathrm{ENO}}$ measurements of the plateau phase were obtained, with $<10 \%$ variation. The mean value of 3 successive, reproducible recordings was retained for statistical analysis.

\section{FEV $_{1}$}

Pulmonary function testing was performed with a Master Screen unit (Erich Jaeger GmbH, Hochberg, Germany). Predicted values for all lung function variables were based on a previous study of healthy controls. ${ }^{15-18}$ Flow-volume curves were performed according to the American Thoracic Society standards. ${ }^{17}$ The highest of 3 successful measurements was taken and analyzed. The results were expressed as the percentage of a predicted value. All the subjects were able to perform spirometry adequately.

\section{Bronchial Reversibility Test}

Reversibility test was performed after the administration of salbutamol (400 $\mu \mathrm{g}$ ), according to the latest Amer- ican Thoracic Society guideline. ${ }^{18}$ The percentage of change from baseline in $\mathrm{FEV}_{1}$ after salbutamol and pre- and postbronchodilator $\mathrm{FEV}_{1}$ values were included in the analysis.

\section{Statistics}

The analysis was performed in 4 different subgroups: (1) episodic asthma, defined as episodic use of low dose, $100-200 \mu \mathrm{g}$ of steroid dose equivalent to budesonide (metered-dose inhaler) daily; (2) mild asthma, defined as medium dose, 200-400 $\mu \mathrm{g}$ of steroid dose equivalent to budesonide (metered-dose inhaler) daily; (3) moderate asthma, defined as high dose, $>400 \mu \mathrm{g}$ of steroid dose equivalent to budesonide (metered-dose inhaler) daily; and (4) healthy subjects. To assess the relationship between $\mathrm{FEV}_{1}$ (as a dependent variable) and $\mathrm{F}_{\mathrm{ENO}}$ level, an analysis of variance (ANOVA) was implemented. Additionally, a test for a linear and nonlinear trend was used. The above relationship was adjusted for the effect of age, sex, presence of allergic rhinitis, allergy profile, and asthma severity. The analysis of variance was implemented to assess the relationship between $\mathrm{FEV}_{1}$ (as a dependent variable) and $\mathrm{F}_{\mathrm{ENO}}$ level categorized according to quartile range; such covariates as age, sex, presence of allergic rhinitis, allergy profile, and asthma severity were also included. The above analysis was performed separately in healthy subjects, in children with episodic asthma, and in children with mild and moderate chronic asthma. All statistical analyses were performed using Statistical Package for the Social Sciences 11.5 (SPSS, Chicago, Illinois). $P<.05$ was considered of statistical significance.

\section{Results}

Data obtained from 405 subjects (children with asthma and healthy controls with all the required tests results) were included in the analysis. Baseline characteristics of the subjects are shown in Table 1. Non-atopic children with asthma who showed normal $\mathrm{F}_{\mathrm{ENO}}$ values were excluded from the analysis. Subjects from the control group were non-asthmatic and non-atopic according to a negative prick test; none had respiratory tract symptoms or were treated with any drug in the 2 months preceding the evaluation of the results.

Median levels of $\mathrm{F}_{\mathrm{ENO}}$ increased linearly with the subjects' age $(P=.03)$. We found a nonlinear trend of prebronchodilator $\mathrm{FEV}_{1}$ across 4 quartiles of $\mathrm{F}_{\mathrm{ENO}}$ in children with asthma without ICS drug (ANOVA, quadratic term: $P=.03$ ) and in children with asthma treated with a low dose of ICS (ANOVA, quadratic term: $P=.049$ ) (Table 2, Fig. 1); we observed lower pre-bronchodilator $\mathrm{FEV}_{1}$ in children with higher $\mathrm{F}_{\mathrm{ENO}}$, but only up to the $\mathrm{F}_{\mathrm{ENO}}$ value of $35.4 \mathrm{ppb}$ (Table 2, Fig. 1); in children with $\mathrm{F}_{\mathrm{ENO}}$ value $>35.4 \mathrm{ppb}$, pre-bronchodilator $\mathrm{FEV}_{1}$ was increased (Ta- 


\section{BRONCHOCONSTRICTION AND EXHALED NitRIC OXIDE}

Table 1. Baseline Characteristics of Subjects

\begin{tabular}{|c|c|c|c|c|}
\hline & $\begin{array}{l}\text { Healthy Subjects } \\
\quad(n=135)\end{array}$ & $\begin{array}{l}\text { Episodic Asthma } \\
\quad(n=65)\end{array}$ & $\begin{array}{l}\text { Mild Asthma } \\
\quad(n=116)\end{array}$ & $\begin{array}{l}\text { Moderate Asthma } \\
\quad(n=89)\end{array}$ \\
\hline Age $(y$, mean $\pm S D)$ & $11.0 \pm 4.7$ & $10.1 \pm 4.0$ & $10.0 \pm 4.4$ & $10.9 \pm 3.5$ \\
\hline Male gender $(n, \%)$ & $72(53.3)$ & $47(72.3)$ & 83 (71.6) & $63(70.8)$ \\
\hline Height $(\mathrm{cm}$, mean $\pm \mathrm{SD})$ & $148.7 \pm 14.6$ & $150.3 \pm 1.2$ & $149.5 \pm 14.8$ & $151.3 \pm 16.1$ \\
\hline Allergic rhinitis & 0 & 31 & 78 & 64 \\
\hline \multicolumn{5}{|l|}{ Allergy profile $(n, \%)$} \\
\hline Non-atopy & $135(100)$ & $11(16.9)$ & $19(16.4)$ & $19(21.3)$ \\
\hline Seasonal only & NA & $6(9.2)$ & $22(19.0)$ & $11(12.4)$ \\
\hline Perennial & NA & $47(72.3)$ & $69(59.5)$ & $58(65.2)$ \\
\hline Food & NA & $1(1.5)$ & $6(5.2)$ & $1(1.1)$ \\
\hline
\end{tabular}

Table 2. Pre-Bronchodilator FEV ${ }_{1}$ According to Four Categories of $\mathrm{F}_{\mathrm{ENO}}$ Level (Defined by Lower/Upper Quartile) in Healthy Subjects and in Children with Episodic, Mild, and Moderate Asthma

\begin{tabular}{|c|c|c|c|c|}
\hline & $\begin{array}{c}\text { Healthy Subjects } \\
(n=135 ; \text { mean } \pm \mathrm{SD})\end{array}$ & $\begin{array}{c}\text { Episodic Asthma } \\
(n=65 ; \text { mean } \pm \text { SD })\end{array}$ & $\begin{array}{c}\text { Mild Asthma } \\
(n=116 ; \text { mean } \pm \mathrm{SD})\end{array}$ & $\begin{array}{c}\text { Moderate Asthma } \\
(n=89 ; \text { mean } \pm \text { SD })\end{array}$ \\
\hline \multicolumn{5}{|l|}{ FeNO (ppb) } \\
\hline$<$ Lower quartile $(<12.8)$ & $105.5 \pm 12.2$ & $104.8 \pm 9.7$ & $102.6 \pm 14.1$ & $103.6 \pm 14.1$ \\
\hline Lower quartile to median $(12.8-19.1)$ & $104.8 \pm 11.4$ & $96.9 \pm 13.1$ & $98.6 \pm 16.7$ & $101.6 \pm 14.5$ \\
\hline Median to higher quartile (19.1-35.4) & $104.7 \pm 11.8$ & $94.7 \pm 16.7$ & $94.6 \pm 14.5$ & $100.0 \pm 11.9$ \\
\hline$>$ Higher quartile $(>35.4)$ & $108.6 \pm 14.0$ & $102.3 \pm 11.7$ & $96.6 \pm 13.8$ & $94.7 \pm 6.8$ \\
\hline \multicolumn{5}{|l|}{ Test for trend (ANOVA)* } \\
\hline Linear term & .43 & .53 & .29 & .039 \\
\hline Quadratic term & .38 & .03 & .049 & .56 \\
\hline \multicolumn{5}{|c|}{$\begin{array}{l}* P \text { values are adjusted for age, sex, allergy profile, and anti-asthma therapy. } \\
\mathrm{F}_{\mathrm{ENO}}=\text { fractional exhaled nitric oxide } \\
\mathrm{ppb}=\text { parts } / \text { billion } \\
\text { ANOVA }=\text { analysis of variance }\end{array}$} \\
\hline
\end{tabular}

ble 2, Fig. 1). In children with moderate asthma, the above trend had linear characteristics (ANOVA, linear term: $P=.039$ ) (Table 2, Fig. 1). In healthy children (without asthma), we did not observe any significant changes in pre-bronchodilator $\mathrm{FEV}_{1}$ across 4 quartiles of $\mathrm{F}_{\mathrm{ENO}}$ (ANOVA, linear term: $P=.43$; quadratic term: $P=.39$ ).

We found a linear increasing trend of change from baseline (after $400 \mu \mathrm{g}$ of salbutamol) in $\mathrm{FEV}_{1}$ across $\mathrm{F}_{\mathrm{ENO}}$ categories in children with moderate asthma (ANOVA, linear term: $P=.02$ ) (Table 3, Fig. 2). In other groups, we did not observe any significant trends of change from baseline (after $400 \mu \mathrm{g}$ of salbutamol) in $\mathrm{FEV}_{1}$ across 4 quartiles of $\mathrm{F}_{\mathrm{ENO}}$ : (1) healthy children (ANOVA, linear term: $P=.36$; quadratic term: $P=.51)$; (2) children with asthma without ICS drug (ANOVA, linear term: $P=.09$; quadratic term: $P=.58$ ); and (3) children with asthma treated with a low dose of ICS (ANOVA, linear term: $P=.84$; quadratic term: $P=.16$ ).
We were not able to demonstrate any significant correlation between $\mathrm{F}_{\mathrm{ENO}}$ value and post-bronchodilator $\mathrm{FEV}_{1}$ (Table 3, Fig. 2).

\section{Discussion}

The current analysis is the first to demonstrate a relationship between the degree of bronchoconstriction and the level of exhaled nitric oxide in a large group of children with asthma. We found a nonlinear trend of prebronchodilator $\mathrm{FEV}_{1}$ across 4 different categories of $\mathrm{F}_{\mathrm{ENO}}$ values in pediatric subjects with episodic and mild asthma. We observed lower pre-bronchodilator $\mathrm{FEV}_{1}$ values in children with higher $\mathrm{F}_{\mathrm{ENO}}$, but only up to the $\mathrm{F}_{\mathrm{ENO}}$ cutoff point of $35.4 \mathrm{ppb}$; in children with $\mathrm{F}_{\mathrm{ENO}}$ value $>35.4 \mathrm{ppb}$, pre-bronchodilator $\mathrm{FEV}_{1}$ was increased. Our study showed that, in children with moderate asthma, the above trend was linear. 

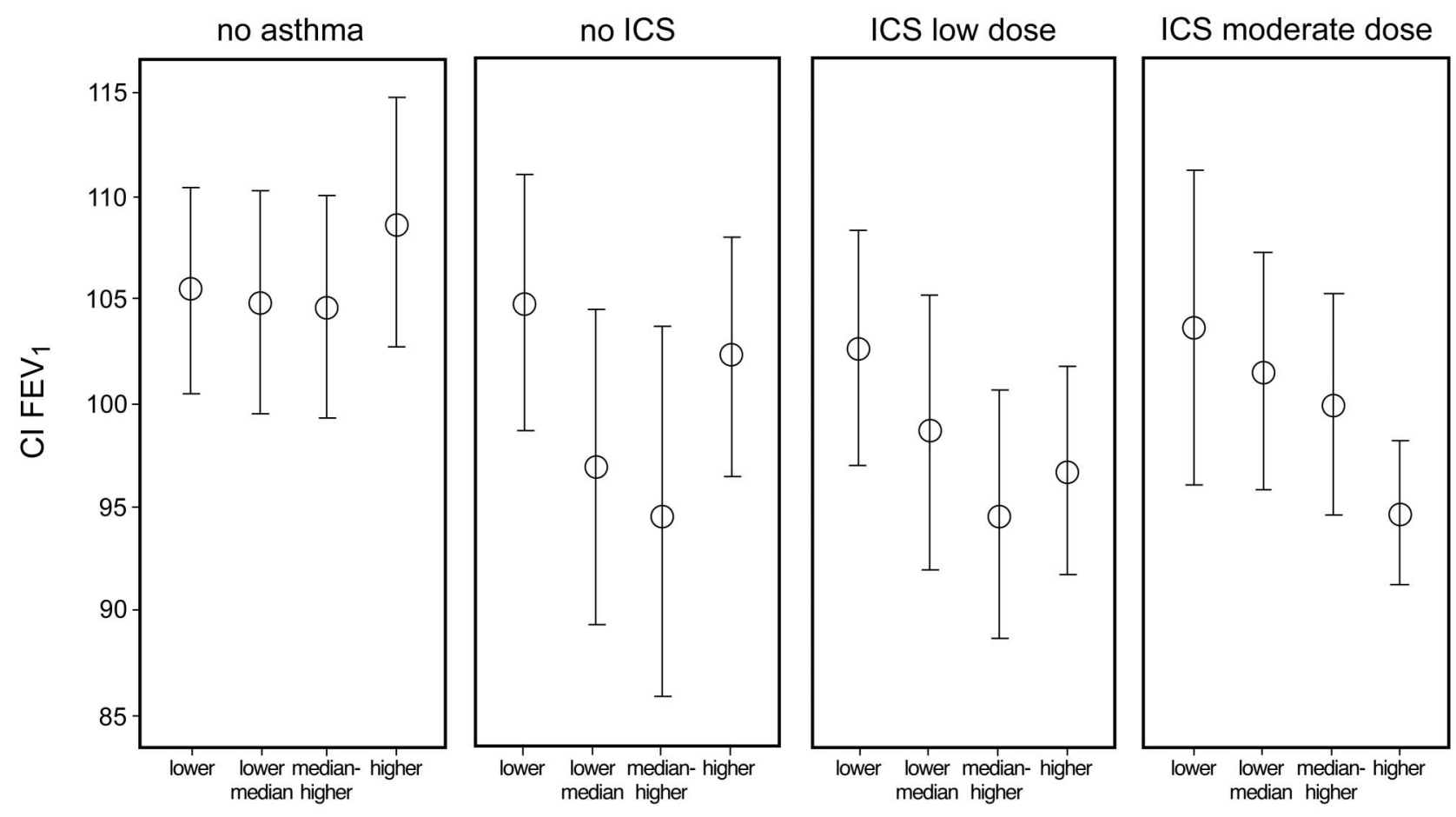

FeNO Quartile

Fig. 1. Pre-bronchodilator $\mathrm{FEV}_{1}$ according to 4 categories of fractional exhaled nitric oxide $\left(\mathrm{F}_{\mathrm{ENO}}\right)$ level (defined by lower/upper quartile) in healthy subjects, in children with asthma without current inhaled corticosteroid therapy (ICS), and in children with asthma treated with low or moderate ICS dose. Data are presented as mean with $95 \% \mathrm{Cl}$.

Table 3. Change from Baseline after $400 \mu \mathrm{g}$ of Salbutamol in $\mathrm{FEV}_{1}$ According to Four Categories of $\mathrm{F}_{\mathrm{ENO}}$ Level (Defined by Lower/Upper Quartile) in Healthy Subjects and in Children with Episodic, Mild, and Moderate Asthma

\begin{tabular}{|c|c|c|c|c|}
\hline & $\begin{array}{l}\text { Healthy Subjects } \\
(n=135 ; \text { mean } \pm \text { SD })\end{array}$ & $\begin{array}{l}\text { Episodic Asthma } \\
(n=65 ; \text { mean } \pm \mathrm{SD})\end{array}$ & $\begin{array}{c}\text { Mild Asthma } \\
(n=116 ; \text { mean } \pm \mathrm{SD})\end{array}$ & $\begin{array}{l}\text { Moderate Asthma } \\
(n=89 ; \text { mean } \pm \mathrm{SD})\end{array}$ \\
\hline \multicolumn{5}{|l|}{$\mathrm{F}_{\mathrm{ENO}}(\mathrm{ppb})$} \\
\hline$<$ Lower quartile $(<12.8)$ & $4.8 \pm 4.8$ & $4.6 \pm 2.7$ & $4.5 \pm 7.0$ & $2.5 \pm 3.1$ \\
\hline Lower quartile to median (12.8-19.1) & $7.2 \pm 7.7$ & $8.2 \pm 6.1$ & $11.4 \pm 18.7$ & $4.6 \pm 5.4$ \\
\hline Median to higher quartile (19.1-35.4) & $3.7 \pm 2.3$ & $12.2 \pm 14.0$ & $5.7 \pm 3.3$ & $3.7 \pm 3.4$ \\
\hline$>$ Higher quartile $(>35.4)$ & $3.5 \pm 5.5$ & $12.1 \pm 11.2$ & $7.0 \pm 9.1$ & $9.4 \pm 10.0$ \\
\hline \multicolumn{5}{|l|}{ Test for trend (ANOVA)* } \\
\hline Linear term & .36 & .09 & .84 & .02 \\
\hline Quadratic term & .51 & .58 & .16 & .28 \\
\hline \multicolumn{5}{|c|}{$\begin{array}{l}\text { * } P \text { values are adjusted for age, sex, allergy profile, and anti-asthma therapy. } \\
\mathrm{ppb}=\text { parts/billion }\end{array}$} \\
\hline
\end{tabular}

We showed that, in episodic and mild asthma, there were 2 trends of $\mathrm{FEV}_{1}$ in relation to $\mathrm{F}_{\mathrm{ENO}}$ : (1) a decreasing linear trend in case of values up to $35.4 \mathrm{ppb}$, (probably as a consequence of inflammation process) and (2) an increasing trend in case of values exceeding $35 \mathrm{ppb}$ (probably as a direct bronchodilator effect of $\mathrm{F}_{\mathrm{ENO}}$ ). This hypothesis seems to be confirmed by the fact that healthy subjects had $\mathrm{F}_{\mathrm{ENO}}$ results $>35.4 \mathrm{ppb}$ and higher $\mathrm{FEV}_{1}$ compared with subjects with asthma. This nonlinear trend suggests that higher $\mathrm{F}_{\mathrm{ENO}}$ may induce bronchodilator response but only in healthy subjects and in episodic and mild chronic asthma. It is within the bounds of possibility that the distinct response of bronchi to higher $\mathrm{F}_{\mathrm{ENO}}$ concentration in moderate asthma could be explained by a more intense inflammation process, resulting in a poor response to a natural autogenic bronchodilator such as 

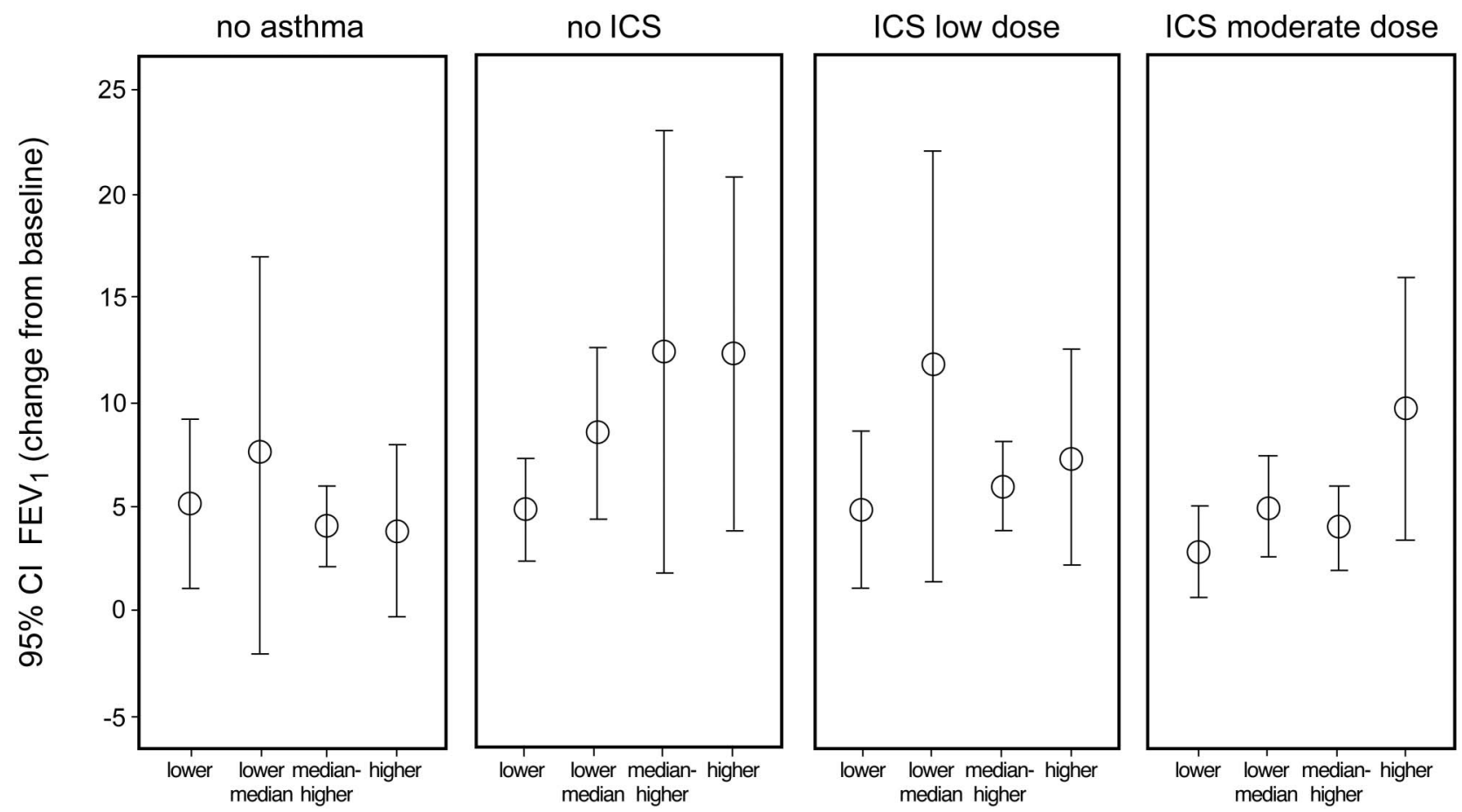

FeNO Quartile

Fig. 2. Change from baseline after $400 \mu \mathrm{g}$ of salbutamol in $\mathrm{FEV}_{1}$ according to 4 categories of fractional exhaled nitric oxide $\left(\mathrm{F}_{\mathrm{ENO}}\right)$ level (defined by lower/upper quartile) in healthy subjects, in children with asthma without current inhaled corticosteroid therapy (ICS), and in children with asthma treated with low or moderate ICS dose. Data are presented as mean with $95 \% \mathrm{Cl}$.

nitric oxide. A limited number of previous studies in children are similar to our results. ${ }^{19,20}$ The study by Cordeiro et $\mathrm{al}^{19}$ showed that the highest diagnostic accuracy of asthma can be achieved by the combination of $\mathrm{F}_{\mathrm{ENO}}(>27 \mathrm{ppb})$ and/or the presence of bronchodilator reversibility. Moreover, it showed that an increased $\mathrm{F}_{\mathrm{ENO}}$ level was positively correlated with the presence of respiratory symptoms and air flow reversibility; however, in their study, all subjects were steroid naive. ${ }^{19} \mathrm{We}$ conducted a similar analysis, and we found a linear increasing trend of change from baseline in bronchial reversibility test using $\mathrm{FEV}_{1}$ values across $4 \mathrm{~F}_{\mathrm{ENO}}$ categories of children with moderate asthma. In contrast with our study, in the study by Cordeiro et al, ${ }^{19}$ the patients were not categorized into different asthma groups nor was the exact number of participants provided. The authors of yet another study identified 4 clusters of subjects with well-controlled asthma versus uncontrolled asthma, associated with increased airway tone; $F_{\mathrm{ENO}}$ did not differ in these 4 clusters. ${ }^{20}$ The authors concluded that $\mathrm{F}_{\mathrm{ENO}}$ is independently linked to ICS-dependent inflammation and bronchomotor tone but does not help to identify a clinically relevant phenotype of children with asthma. ${ }^{20}$ We showed that, in children with episodic/mild asthma, $\mathrm{F}_{\mathrm{ENO}}$, in a certain concentration of $>35.4 \mathrm{ppb}$ may act as a significant bronchodilator. To our knowledge, there exists no other study to date (using our model) that fully supports our results. Moreover, there is no general consensus about correlation between $\mathrm{F}_{\mathrm{ENO}}$ and respiratory function in children. ${ }^{2,21-34}$

The main limitation of our study is the retrospective design. We gathered data from the subjects' medical documentation, which could partly have influenced the accuracy of our results. The same could be true for a relatively wide range of the subjects' age (from 6 to $18 \mathrm{y}$ ). However, all subjects participating in this study remain under the regular care of specialists from our clinic, including physical examination, lung function measurements, and other necessary tests, which excludes any doubts concerning the heterogeneity of diagnostic and therapeutic procedures. Therefore, all lung function tests were performed according to guidelines..$^{14-18}$

Another limitation of our study is that, because it was a retrospective study, we analyzed medical data of different phenotypes of asthma. However, the various groups of children with asthma that we defined in our study do not seem to differ significantly as far as their lung function is concerned, presumably because they are all reasonably controlled on their ICS. In turn, this could have affected the results we obtained regarding both $\mathrm{F}_{\mathrm{ENO}}$ and lung function. We suspect that it would be best to study subjects off ICS to remove its effect on both parameters. When interpreting our results, it should be kept in mind that even if 


\section{BRONCHOCONSTRICTION AND EXHALED NitRIC OXIDE}

a certain medication, such as short-acting $\beta_{2}$ agonist, does not affect NO production, it might affect the apparent level of NO through other mechanisms such as changes in airway caliber, which so far has been shown only in the studies of adults, as cited in the guideline. ${ }^{31}$ Until now, studies in children have revealed the opposite, namely that $\mathrm{F}_{\mathrm{ENO}}$ does not significantly change after long- or shortacting bronchodilators, which have no known anti-inflammatory effect. ${ }^{32,33} \mathrm{We}$ carefully noted that, in many of the clinical studies in adults, it is advised to perform $\mathrm{F}_{\mathrm{ENO}}$ measurements before any other lung function measurement and even before usage of short-acting $\beta_{2}$ agonists, ${ }^{34,35}$ and the same order of measurements and procedures is followed by most of the studies in children. ${ }^{19,20,36}$ It does not seem justified in the context of our results in children with asthma. Therefore, our results reveal important new clinical aspects regarding the order of measurements in children with asthma. The regulation of both exhaled NO and bronchomotor tone is intriguingly complex in childhood asthma, ${ }^{2}$ and it is also possible that slightly higher or lower $\mathrm{FEV}_{1}$ in those subjects with the highest $\mathrm{F}_{\mathrm{ENO}}$ values may not serve as an indicator of physiological interactions. It has been well documented that $\mathrm{F}_{\mathrm{ENO}}$ falls by approximately $20 \%$ after forced expiratory maneuvers in adults, probably as a consequence of depleted tissue stores. ${ }^{31}$ Thus, the standard recommendation of performing $\mathrm{F}_{\mathrm{ENO}}$ measurement before spirometry may continue to seem a logical choice; nevertheless, clinicians must be aware of the multiple factors influencing $\mathrm{F}_{\mathrm{ENO}}$ and draw sensible conclusions. ${ }^{2}$ The authors are also aware that the bronchodilator effect of salbutamol is determined not only by inflammation but also genetic variability of $\beta_{2}$ receptor expression ${ }^{1}$; hence, there is a possibility that $\Delta\left(\mathrm{FEV}_{1}\right)$ in subjects without a significant bronchodilator effect may not always be a valid variable.

\section{Conclusions}

Pediatricians and allergists expect that $\mathrm{F}_{\mathrm{ENO}}$ is an inflammometer but not a lung function indicator. It is reasonable to use a ratio, $\mathrm{F}_{\mathrm{ENO}} / \mathrm{FEV}_{1}$, which could probably overcome doubts concerning the adequate measurement of inflammation by $\mathrm{F}_{\mathrm{ENO}}$; however, it still requires validation. The conclusion of our study is that, independent of the influence of $\mathrm{FEV}_{1}$ on $\mathrm{F}_{\mathrm{ENO}}$ value, such relationship has obvious clinical implications, which suggest a need to measure $\mathrm{F}_{\mathrm{ENO}}$ before and after spirometry and, consequently, in children with symptomatic asthma, to assess $\mathrm{F}_{\mathrm{ENO}}$ after short-acting $\beta_{2}$ agonists as well.

\section{REFERENCES}

1. GINA Report, Global Strategy for Asthma Management and Prevention, 2012 http://www.ginasthma.org/. Accessed November 2013.
2. Dweik RA, Boggs PB, Erzurum SC, Irvin CG, Leigh MW, Lundberg JO, et al. American Thoracic Society Committee on Interpretation of Exhaled Nitric Oxide Levels (FENO) for Clinical Applications. An official ATS clinical practice guideline: interpretation of exhaled nitric oxide levels (FENO) for clinical applications. Am J Respir Crit Care Med 2011;184(5):602-615.

3. Grzelewski T, Grzelewska A, Majak P, Stelmach W, Kowalska A, Stelmach R, et al. Fractional exhaled nitric oxide (FeNO) may predict exercise-induced bronchoconstriction (EIB) in schoolchildren with atopic asthma. Nitric Oxide 2012;27(2):82-87.

4. Grzelewski T, Majak P, Jerzyńska J, Cichalewski L, Krakowiak J, Stelmach W, et al. The association between fractional exhaled nitric oxide (FeNO) and cat dander in asthmatic children. Nitric Oxide 2011;25(3):288-293.

5. Hamid Q, Springall DR, Riveros-Moreno V, Chanez P, Howarth P, Redington A, et al. Induction of nitric oxide synthase in asthma. Lancet 1993;342(8886-8887):1510-1513.

6. Redington AE, Meng QH, Springall DR, Evans TJ, Créminon C, Maclouf $\mathrm{J}$, et al. Increased expression of inducible nitric oxide synthase and cyclo-oxygenase- 2 in the airway epithelium of asthmatic subjects and regulation by corticosteroid treatment. Thorax 2001; 56(5):351-357.

7. Guo FH, Comhair SA, Zheng S, Dweik RA, Eissa NT, Thomassen $\mathrm{MJ}$, et al. Molecular mechanisms of increased nitric oxide (NO) in asthma: evidence for transcriptional and post-translational regulation of NO synthesis. J Immunol 2000;164(11):5970-5980.

8. Green RJ, Klein M, Becker P, Halkas A, Lewis H, Kitchin O, et al. Disagreement among common measures of asthma control in children. Chest 2013;143(1):117-122.

9. Strunk RC, Szefler SJ, Phillips BR, Zeiger RS, Chinchilli VM, Larsen G, et al. Childhood Asthma Research and Education Network of the National Heart, Lung, and Blood Institute: Relationship of exhaled nitric oxide to clinical and inflammatory markers of persistent asthma in children. J Allergy Clin Immunol 2003;112(5):883-892.

10. Miraglia del Giudice M, Piacentini GL, Capasso M, Capristo C, Maiello N, Boner AL, Capristo AF. Formoterol, montelukast, and budesonide in asthmatic children: effect on lung function and exhaled nitric oxide. Respir Med 2007;101(8):1809-1813.

11. Ramser M, Hammer J, Amacher A, Trachsel D. The value of exhaled nitric oxide in predicting bronchial hyperresponsiveness in children. J Asthma 2008;45(3):191-195.

12. del Giudice MM, Brunese FP, Piacentini GL, Pedullà M, Capristo C, Decimo F, Capristo AF. Fractional exhaled nitric oxide (FENO), lung function and airway hyperresponsiveness in naïve atopic asthmatic children. J Asthma 2004;41(7):759-765.

13. Bousquet J, Khaltaev N, Cruz AA, Denburg J, Fokkens WJ, Togias A, et al. World Health Organization; GA(2)LEN; AllerGen. Allergic Rhinitis and its Impact on Asthma (ARIA) 2008 update (in collaboration with the World Health Organization, GA(2)LEN and AllerGen). Allergy 2008;63(Suppl 86):8-160.

14. Recommendations for standardized procedures for the on-line and off-line measurement of exhaled lower respiratory nitric oxide and nasal nitric oxide in adults and children-1999. This official statement of the American Thoracic Society was adopted by the ATS Board of Directors, Jul 1999. Am J Respir Crit Care Med 1999;160(6):21042117.

15. Quanjer PH, Tammeling GJ, Cotes JE, Fabbri LM, Matthys H, Pedersen OF, et al. Symbols abbreviations and units. Working Party Standardization of Lung Function Tests, European Community for Steel and Coal. Eur Respir J Suppl. 1993 Mar; 16:85-100.

16. Quanjer PhH, Helms P, Bjure J, Gaultier C. Standardization of lung function tests in paediatrics. Eur Respir J 1989;2(Suppl 4):184s$261 \mathrm{~s}$. 


\section{BronchoCONSTRICTION AND EXHALED NitRIC OXIDE}

17. Miller MR, Hankinson J, Brusasco V, Burgos F, Casaburi R, Coates A, et al. ATS/ERS Task Force. Standardisation of spirometry. Eur Respir J 2005;26(2):319-338.

18. Pellegrino R, Viegi G, Brusasco V, Crapo RO, Burgos F, Casaburi $\mathrm{R}$, et al. Interpretative strategies for lung function tests. Eur Respir $\mathrm{J}$ 2005;26(5):948-968.

19. Cordeiro D, Rudolphus A, Snoey E, Braunstahl GJ. Utility of nitric oxide for the diagnosis of asthma in an allergy clinic population. Allergy Asthma Proc 2011;32(2):119-126.

20. Mahut B, Peyrard S, Delclaux C. Exhaled nitric oxide and clinical phenotypes of childhood asthma. Respir Res 2011;12(1):65-73.

21. Nathan C, Xie QW. Nitric oxide synthases: roles, tolls, and controls. Cell 1994;78(6):915-918.

22. Dweik RA, Comhair SA, Gaston B, Thunnissen FB, Farver C, Thomassen MJ, et al. NO chemical events in the human airway during the immediate and late antigen-induced asthmatic response. Proc Natl Acad Sci USA 2001;98(5):2622-2627.

23. Ricciardolo FL. Multiple roles of nitric oxide in the airways. Thorax 2003;58(2):175-182.

24. Khatri SB, Hammel J, Kavuru MS, Erzurum SC, Dweik RA. Temporal association of nitric oxide levels and airflow in asthma after whole lung allergen challenge. J Appl Physiol 2003;95(1):436-440.

25. Khatri SB, Ozkan M, McCarthy K, Laskowski D, Hammel J, Dweik RA, Erzurum SC. Alterations in exhaled gas profile during allergeninduced asthmatic response. Am J Respir Crit Care Med 2001;164(10 Pt 1):1844-1848.

26. Spergel JM, Fogg MI, Bokszczanin-Knosala A. Correlation of exhaled nitric oxide, spirometry and asthma symptoms. J Asthma 2005; 42(10):879-883.

27. Vahlkvist S, Sinding M, Skamstrup K, Bisgaard H. Daily home measurements of exhaled nitric oxide in asthmatic children during natural birch pollen exposure. J Allergy Clin Immunol 2006;117(6): 1272-1276.

28. Paro-Heitor ML, Bussamra MH, Saraiva-Romanholo BM, Martins MA, Okay TS, Rodrigues JC. Exhaled nitric oxide for monitoring childhood asthma inflammation compared to sputum analysis, serum interleukins and pulmonary function. Pediatr Pulmonol 2008;43(2): 134-141.

29. Piacentini GL, Peroni DG, Bodini A, Bonafiglia E, Rigotti E, Baraldi E, et al. Childhood Asthma Control Test and airway inflammation evaluation in asthmatic children. Allergy 2009;64(12):17531757.

30. Stelmach I, Kaluzińska-Parzyszek I, Jerzynska J, Stelmach P, Stelmach W, Majak P. Comparative effect of pre-coseasonal and continuous grass sublingual immunotherapy in children. Allergy 2012; 67(3):312-320

31. American Thoracic Society, European Respiratory Society. ATS/ ERS recommendations for standardized procedures for the online and offline measurement of exhaled lower respiratory nitric oxide and nasal nitric oxide. Am J Respir Crit Care Med 2005;171(8):912930

32. Baraldi E, de Jongste JC, European Respiratory Society/American Thoracic Society (ERS/ATS) Task Force. Measurement of exhaled nitric oxide in children. Eur Respir J 2002;20(1):223-237.

33. Colon-Semidey AJ, Marshik P, Crowley M, Katz R, Kelly HW. Correlation between reversibility of airway obstruction and exhaled nitric oxide levels in children with stable bronchial asthma. Pediatr Pulmonol 2000;30(5):385-392.

34. Papakosta D, Latsios D, Manika K, Porpodis K, Kontakioti E, Gioulekas D. Asthma control test is correlated to FEV1 and nitric oxide in Greek asthmatic patients: influence of treatment. J Asthma 2011; 48(9):901-906.

35. Yasui H, Fujisawa T, Inui N, Kato M, Hashimoto D, Enomoto N, et al. Impact of add-on pranlukast in stable asthma; the additive effect on peripheral airway inflammation. Respir Med 2012;106(4):508514.

36. Banovcin P, Jesenak M, Michnova Z, Babusikova E, Nosal S, Mikler $\mathrm{J}$, et al. Factors attributable to the level of exhaled nitric oxide in asthmatic children. Eur J Med Res 2009;14(Suppl 4):9-13. 